appeal to all pathologists to increase their contributions so far as they are able.

Note on Patients. - A number of these cases are described by Clayton et al. (1967). The reference numbers relate as follows:

\begin{tabular}{|c|c|c|c|c|c|}
\hline $\begin{array}{l}\text { This } \\
\text { Paper }\end{array}$ & $\begin{array}{c}\text { Clayton } \\
\text { et al. }\end{array}$ & $\begin{array}{l}\text { This } \\
\text { Paper }\end{array}$ & $\begin{array}{c}\text { Clayton } \\
\text { et al. }\end{array}$ & $\begin{array}{l}\text { This } \\
\text { Paper }\end{array}$ & $\begin{array}{l}\text { Clayton } \\
\text { et al. }\end{array}$ \\
\hline $\begin{array}{l}4 \\
5 \\
7 \\
8 \\
9\end{array}$ & $\begin{array}{ll}\because . & 3.1 \\
\because . & 3.2 \\
\because . & 3.3 \\
\because \therefore & 3.7 \\
\because .11 & 3.11\end{array}$ & $\begin{array}{l}10 \\
11 \\
12 \\
14 \\
15\end{array}$ & $\begin{array}{cr}0 & 3.12 \\
\because \therefore & 3.13 \\
\because \therefore & 3.14 \\
\because \therefore & 3.18 \\
\because .16\end{array}$ & $\begin{array}{l}16 \\
17 \\
18 \\
19 \\
22\end{array}$ & $\begin{array}{ll}. . & 3.17 \\
\therefore & 3.24 \\
\because . & 3.21 \\
\therefore & 3.25 \\
\therefore & 1.10\end{array}$ \\
\hline
\end{tabular}

\section{Appendix I}

Pituitary glands should be stored in acetone and sent direct to Dr. Anne Hartree, Department of Biochemistry, Cambridge. A small sum plus the postage may be reclaimed by application to the Medical Research Council, 20 Park Crescent, London W.1, from whom further details of procedure may be obtained if required. Glands from persons of all ages are suitable.

\section{Appendix II}

Collectors of glands were instructed to put them in $20 \mathrm{ml}$. of acetone, which could subsequently be replaced by a smaller volume of acetone. Batches of glands were pooled and fractionated. The extract containing growth hormone was put in 20- to $60-\mathrm{g}$. batches, and then dissolved in $0.05 \mathrm{~N} \mathrm{NaOH}$, adjusted to $\mathrm{pH} 7.5$ to 8.5 with $0.1 \mathrm{~N} \mathrm{HCl}$, and diluted to $10 \mathrm{mg} . / \mathrm{ml}$. After sterilization by filtration through a membrane of average pore diameter $0.45 \mu$ the solution was freeze-dried in 1-ml. amounts in ampoules, which were then sealed. Each batch of ampoules passed the B.P. 1963 tests for bacterial sterility and freedom from pyrogens (at 5 i.u. $/ \mathrm{kg}$. rabbit body weight).

The potency of each batch, compared with the international standard, is shown in Table II. The estimate of prolactin activity is also given. Batches R5 to R9 were also assayed for antidiuretic activity, and, with the use of rats under a constant water load, found to have some 0.05 to $0.15 \mathrm{i} . \mathrm{u} . / \mathrm{mg}$.

TABLE II

\begin{tabular}{|c|c|c|c|}
\hline \multirow[b]{2}{*}{ Batch } & \multicolumn{2}{|c|}{ Growth Activity* } & \multirow{2}{*}{$\begin{array}{c}\text { Prolactin Activity† } \\
\text { (i.u. per Nominal } 10 \mathrm{mg} \text {. } \\
\text { of Growth Hormone } \$ \text { ) }\end{array}$} \\
\hline & $\begin{array}{l}\text { i.u. per Nominal 10-mg. } \\
\text { Ampoule } \neq\end{array}$ & $\begin{array}{l}\text { i.u. per mg. } \\
\text { (Specific } \\
\text { Activity) }\end{array}$ & \\
\hline $\begin{array}{l}\text { R4 } \\
\text { R5 } \\
\text { R6 } \\
\text { R7 } \\
\text { R8 } \\
\text { R9 }\end{array}$ & $\begin{aligned} 7 \cdot 2 & (5 \cdot 2-10 \cdot 2) \\
11.0 & (8 \cdot 0-15 \cdot 2) \\
11.9 & (8 \cdot 8-16 \cdot 9) \\
5.6 & (4 \cdot 3-7 \cdot 3) \\
6 \cdot 2 & (4 \cdot 0-9 \cdot 4) \\
12 \cdot 1 & (10 \cdot 3-14 \cdot 2)\end{aligned}$ & $\begin{array}{l}0.63 \\
? \\
1 \cdot 14 \\
0 \cdot 83 \\
0.68 \\
1 \cdot 23\end{array}$ & $\begin{array}{l}17.7(10 \cdot 8-29 \cdot 1) \\
22.9(17 \cdot 0-30 \cdot 7) \\
15.4(0.76-186 \cdot 2) \\
11.5((6.4-15 \cdot 6) \\
25.7(14.9-44.4) \\
74.8(39 \cdot 2-210 \cdot 9)\end{array}$ \\
\hline
\end{tabular}

REFERENCES

Clayton, B. E., Tanner, J. M., Newns, G. H., Whitehouse, R. H., and Renwick, A. G. L. (1967). Arch. Dis. Childh. In press.

Hartree, A. S. (1966). Biochem. F., 100, 754

Mason, A. S., and Tanner, J. M. (1967). In Modern Trends in Endo- ov crinology, edited by Gardiner Hill. London. In press. Arch. Dis.

Prader, A., Illig, R., Széky, J., and Wagner, H. (1964). Arch.

Childh., 39, 535. Wagner, H., Széky, Illig, R., Touber, J. L., and Maingay, D. O (1964). Lancet, 2, 378 .

Raben, M. S. (1959). 'Recent Progr. Hormone Res., 15, 71.

(1965). Proceedings of the 2nd International Congress on Endo- I crinology, p. 989 . London.

Seip, M., and Trygstad, O. (1966). Acta paediat. (Uppsala), 55, 287. Soyka, L. F., Ziskind, A., and Crawford, J. D. (1964). New Engl. 7. Med., 271,754

Széky, J., Hässig, A., and Prader, A. (1962). Helv. paediat. Acta, 17, 411. Tanner, T. M. (1962). Growth at Adolescence, 2nd ed. Oxford.

- (1963). Nature (Lond.), 199, 845.

(1964). Physique of the Olympic Athlete. London.

and Whitehouse, R H (1955) Amer 7. phys. Anthrop. 13, 743 . (1967) Submitted for publication.

- and Healy, M. J. R. (1962). A New System for Estimating Oे

Skeletal Maturity from the Hand and Wrist, with Standards Derived

from a Study of 2,600 Healthy British Children. Parts I and II. Q Centre Internationale de L'Enfance, Paris.

W. and Takaishi, M. (1966). Arch. Dis. Childh., 41, 454, 613.

Wright, J. C., et al. (1965). Amer. F. Med., 38, 499.

\title{
Modification by Monoamine Oxidase Inhibitors of the Effect of Some Sympathomimetics on Blood Pressure
}

\author{
J. ELIS,* M.D. ; D. R. LAURENCE, $\dagger$ M.D., F.R.C.P. ; H. MATTIE, $\ddagger$ M.B \\ B. N. C. PRICHARD, $†$ M.SC., M.B., M.R.C.P.
}

Brit. med. 9., 1967, 2, 75-78

The importance to clinicians of knowledge of interactions between sympathomimetics, whether taken as drugs or in food, and monoamine oxidase inhibitors has been self-evident since the accidental discovery in clinical practice that these interactions can cause not merely an unpleasant experience but even death. It is salutary to reflect that, though the interactions were predictable on theoretical grounds, and can be induced in animals, they were not in fact predicted, so that no warnings were given when the drugs went into clinical use.

Little formal experimentation in man has been done, probably because of the drama of the initial clinical experiences, and therefore little is known of the size of the risks of ordinary dosage of sympathomimetics.

The experiments reported here were undertaken to provide some knowledge of the magnitude of this risk from different kinds of sympathomimetic and different kinds of monoamine oxidase inhibitor. They are few in number, not because they were thought to be particularly dangerous-careful observation $\stackrel{0}{ᄃ}$ in a clinical pharmacological laboratory with the ready avail- $\mathbb{D}$ ability of the $\alpha$-adrenergic receptor blocking drug, phentolamine, was thought to render the experiments safe enough to be justified-but because it is not easy to find people willing to spend the necessary time in the laboratory as well as to take a monoamine oxidase inhibitor for one or more weeks.

It was thought unethical to atternpt to perform the experiments on patients taking monoamine oxidase inhibitors for mental disorder.

\footnotetext{
* Institute of Pharmacology, Czechoslovak Academy of Sciences, W.H.O

Fellow Unit, University College Hospital Medical School, London W. 1 .

‡ Department of Pharmacology, University of Leiden, Netherlands.
} 


\section{Methods}

The four experimental subjects were apparently normal male pharmacologists. This presented a difficulty in that the subjects were not ignorant of the possible results of the experiments. It was not thought practicable to spend prolonged periods over dummy experiments, and subjects knew when they were taking a monoamine oxidase inhibitor. During the acute experiments, as a compromise, it was ensured that where intravenous infusion was used the subject was ignorant of when it changed from physiological saline to active drug ; and where oral administration was used the subject took a series of five or six doses in capsules of identical appearance at intervals of 20 to 30 minutes,

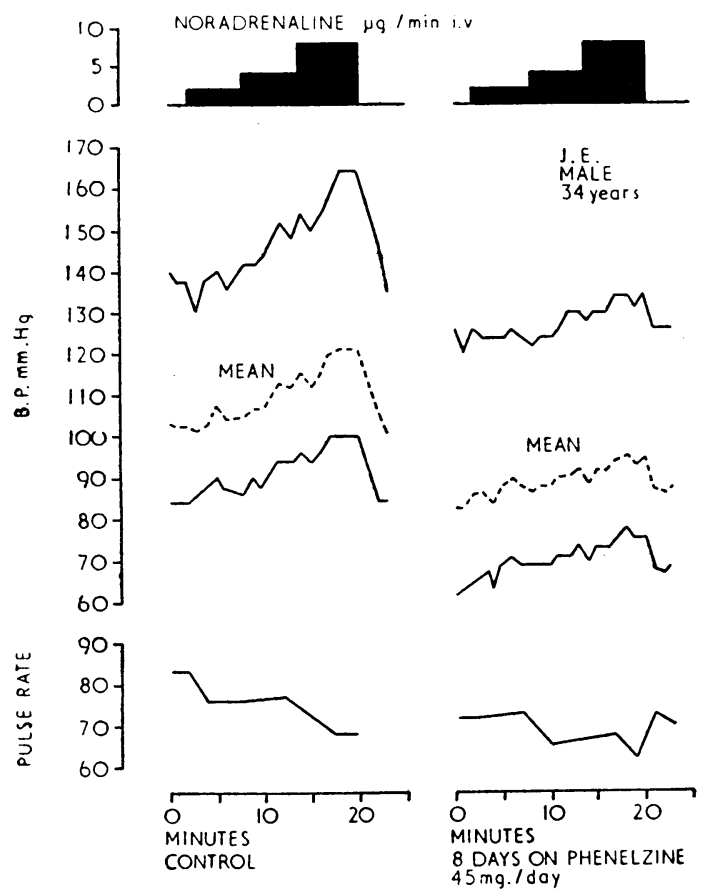

Fig. 1.-Effect of intravenous noradrenaline on the blood pressure and heart rate before and during phenelzine administration. Phenelzine lowered the blood pressure, so that exact comparison is impossible, but there is no evidence of potentiation. only one of which contained the active substance. Both subject and investigator were ignorant of which oral dose was the active one. The ideal of keeping the subject in ignorance of what he has received and when he has received it cannot be achieved wherever substantial rises of blood pressure occur, owing to the subjective sensations induced.

Experiments consisted in measuring blood pressure and pulse rate and monitoring the electrocardiogram, in supine subjects, before, during, and for an appropriate period after administration of the sympathomimetic, depending on the drug and the route by which it was given. In each subject the sympathomimetic was given before, during, and usually after a course of monoamine oxidase inhibitor (tranylcypromine or phenelzine) taken orally.

The sympathomimetics used were phenylephrine and ephedrine orally and intravenously and noradrenaline intra-
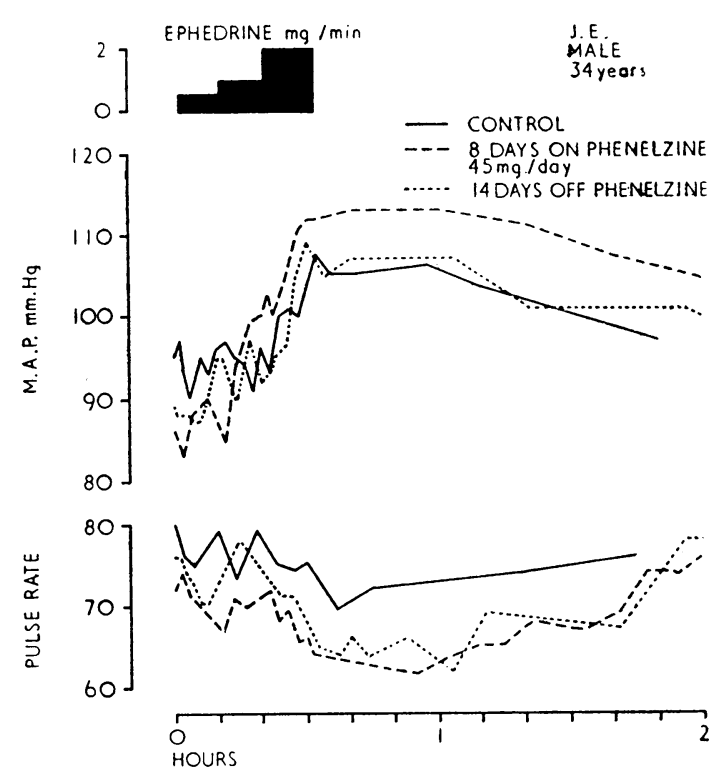

FIG. 2.-Effect of intravenous ephedrine on arterial mean pressure and heart rate before, during, and after a course of phenelzine. The rise in blood pressure is both of phenelzine. The rise in blood press

Control Values and Maximal Changes of Mean Arterial Pressure Due to Sympathomimetic Amines Before, During, and After Monoamine Oxidase Inhibition

\begin{tabular}{|c|c|c|c|c|c|c|c|c|c|c|c|}
\hline \multirow[b]{2}{*}{ Subject } & \multirow[b]{2}{*}{$\begin{array}{l}\text { Monoamine } \\
\text { Oridase } \\
\text { Inhibitor }\end{array}$} & \multirow[b]{2}{*}{ Drug } & \multirow[b]{2}{*}{ Dosage } & \multirow[b]{2}{*}{$\begin{array}{c}\text { Days } \\
\text { on } \\
\text { M.A.O.I. }\end{array}$} & \multirow[b]{2}{*}{$\begin{array}{c}\text { Control } \\
\text { Value of } \\
\text { Mean } \\
\text { Arterial } \\
\text { Pressure } \\
\text { (mm. Hg) }\end{array}$} & \multirow[b]{2}{*}{$\underset{\text { Chm. Hg) }}{\text { Caximal }}$} & \multirow[b]{2}{*}{$\begin{array}{c}\% \text { of } \\
\text { Control }\end{array}$} & \multicolumn{4}{|c|}{ After Discontinuing M.A.O. Inhibitor } \\
\hline & & & & & & & & Days & $\begin{array}{c}\text { Control } \\
\text { Value of } \\
\text { Mean } \\
\text { Arterial } \\
\text { Pressure }\end{array}$ & $\underset{\text { Change }}{\text { Maximal }}$ & $\begin{array}{c}\% \text { of } \\
\text { Control }\end{array}$ \\
\hline J.E. & $\begin{array}{l}\text { Phenelzine } \\
45 \mathrm{mg} \cdot / \text { day }\end{array}$ & Noradrenaline i.v. \{ & $\begin{array}{l}2 \mu \mathrm{g} . / \mathrm{min} . \times 6 \mathrm{~min} . \\
4 \mathrm{gg} / \mathrm{min} . \times 6 \mathrm{~min} . \\
8 \mu \mathrm{g} . / \mathrm{min} . \times 6 \mathrm{~min} .\end{array}$ & $\begin{array}{l}0 \\
\frac{1}{7}\end{array}$ & $\begin{array}{r}102 \\
89 \\
84\end{array}$ & $\begin{array}{l}+19 \\
+13 \\
+12\end{array}$ & $\begin{array}{l}+18 \cdot 6 \\
+14 \cdot 6 \\
+14 \cdot 2\end{array}$ & & & & \\
\hline J.B. & - & Ephedrine i.v. $\quad\{$ & $\begin{array}{l}0.5 \mathrm{mg} . / \mathrm{min} . \times 6 \mathrm{~min} . \\
1 \mathrm{mg} . / \mathrm{min} . \times 6 \mathrm{~min} . \\
2 \mathrm{mg} . / \mathrm{min} . \times 6 \mathrm{~min} .\end{array}$ & $\begin{array}{l}0 \\
2 \\
9\end{array}$ & $\begin{array}{l}96 \\
92 \\
86\end{array}$ & $\begin{array}{l}+12 \\
+15 \\
+27\end{array}$ & $\begin{array}{l}+12 \cdot 5 \\
+16 \cdot 3 \\
+31 \cdot 4\end{array}$ & 14 & 88 & +19 & $+21 \cdot 6$ \\
\hline J.B. & $"$ & Ephedrine orally & $30 \mathrm{mg}$ & $\begin{array}{r}0 \\
13\end{array}$ & $\begin{array}{r}104 \\
89\end{array}$ & $\begin{array}{l}+6 \\
+20\end{array}$ & $\begin{array}{l}+5 \cdot 8 \\
+22 \cdot 5\end{array}$ & $\begin{array}{r}9 \\
16 \\
28\end{array}$ & $\begin{array}{l}85 \\
89 \\
92\end{array}$ & $\begin{array}{l}+20 \\
+15 \\
+9\end{array}$ & $\begin{array}{l}+23.5 \\
+16.8 \\
+9.8\end{array}$ \\
\hline R.H. & " & $"$ & $30 \mathrm{mg}$. & $\begin{array}{r}0 \\
7 \\
14\end{array}$ & $\begin{array}{l}77 \\
79 \\
84\end{array}$ & $\begin{array}{l}+5 \\
+14 \\
+22\end{array}$ & $\begin{array}{l}+6.5 \\
+17.7 \\
+26.3\end{array}$ & $\begin{array}{r}7 \\
21\end{array}$ & $\begin{array}{l}82 \\
80\end{array}$ & $\begin{array}{l}+25 \\
+3\end{array}$ & $\begin{array}{l}+30.5 \\
+3.8\end{array}$ \\
\hline A.O. & $\begin{array}{l}\text { Tranylcypromine } \\
30 \mathrm{mg} . / \mathrm{day}\end{array}$ & . & $30 \mathrm{mg}$. & $\begin{array}{l}0 \\
5\end{array}$ & $\begin{array}{l}78 \\
83\end{array}$ & $\begin{array}{l}+4 \\
+14\end{array}$ & $\begin{array}{l}+5 \cdot 1 \\
+16.8\end{array}$ & 24 & $\begin{array}{l}88 \\
79\end{array}$ & $\begin{array}{l}+22 \\
+7\end{array}$ & $\begin{array}{l}+25 \cdot 0 \\
+8.8\end{array}$ \\
\hline J.B. & $" \quad, *$ & $"$ & $30 \mathrm{mg}$. & $\begin{array}{r}0 \\
5 \\
12\end{array}$ & $\begin{array}{l}93 \\
89 \\
86\end{array}$ & $\begin{array}{l}+6 \\
+15 \\
+22\end{array}$ & $\begin{array}{l}+6.4 \\
+16.8 \\
+25.6\end{array}$ & $\begin{array}{l}10 \\
21\end{array}$ & $\begin{array}{l}83 \\
89\end{array}$ & $\begin{array}{l}+24 \\
+11\end{array}$ & $\begin{array}{l}+28 \cdot 9 \\
+12 \cdot 4\end{array}$ \\
\hline J.B. & Phenelzine & $\begin{array}{l}\text { Phenylephrine orally } \\
\text { (phentolamine) }\end{array}$ & $45 \mathrm{mg}$. & $\mathbf{0}$ & $\begin{array}{l}94 \\
90\end{array}$ & $\begin{array}{l}+1 \\
+67 t\end{array}$ & $\begin{array}{r}+1.8 \\
+74.4\end{array}$ & 7 & 85 & +9 & $+10 \cdot 6$ \\
\hline J.E. & Tranylcypromine & Phenylephrine orally & $45 \mathrm{mg}$. & $\begin{array}{l}0 \\
7\end{array}$ & $\begin{array}{l}94 \\
91\end{array}$ & $\begin{array}{l}+4 \\
+48\end{array}$ & $\begin{array}{l}+4 \cdot 3 \\
+52 \cdot 8\end{array}$ & 7 & 91 & +10 & $+11 \cdot 0$ \\
\hline A.O. & " & $\begin{array}{l}\text { Phenylephrine orally } \\
\text { (phentolamine) }\end{array}$ & $45 \mathrm{mg} . \quad\{$ & $\begin{array}{l}0 \\
7\end{array}$ & $\begin{array}{l}86 \\
90\end{array}$ & $\begin{array}{l}+11 \\
+67 \dagger\end{array}$ & $\begin{array}{l}+12 \cdot 8 \\
+74 \cdot 4\end{array}$ & 7 & 85 & +12 & $+14 \cdot 6$ \\
\hline D.L. & $\begin{array}{l}\text { Phenelzine } \\
45 \text { mg./day }\end{array}$ & Phenylephrine i.v. \{ & $\begin{array}{l}0.1 \mathrm{mg} . / \mathrm{min} . \times 10 \mathrm{~min} . \\
0.2 \mathrm{mg} . / \mathrm{min} . \times 10 \mathrm{~min} .\end{array}$ & $\begin{array}{l}\mathbf{0} \\
\mathbf{7}\end{array}$ & $\begin{array}{l}85 \\
87\end{array}$ & $\begin{array}{l}+23 \\
+45\end{array}$ & $\begin{array}{l}+27 \cdot 1 \\
+51 \cdot 7\end{array}$ & & & & \\
\hline D.L. & Tranylcypromine & Phenylephrine orally \{ & $\begin{array}{l}3 \mathrm{mg} . \\
10 \mathrm{mg}\end{array}$ & 11 & $\begin{array}{l}87 \\
87\end{array}$ & $\begin{array}{l}+7 \\
+20\end{array}$ & $\begin{array}{l}+8 \cdot 0 \\
+23 \cdot 0\end{array}$ & 21 & 87 & +7 & $+8 \cdot 0$ \\
\hline
\end{tabular}


venously. A small rise of blood pressure is attributed to a drug only if it is accompanied by bradycardia.

\section{Results}

Eleven experiments were done in four subjects. In six the monoamine oxidase inhibitor was phenelzine and in five it was tranylcypromine. The initial intention of duplicating each administration of sympathomimetic with each monoamine oxidase inhibitor was abandoned after it had been done with ephedrine and phenylephrine with similar results, as the tedium of the project was found to be even greater than was at first supposed.

Detailed results are shown in the Table, where the blood pressure is represented as mean arterial pressure. The pattern of change-a rise in both systolic and diastolic pressure, with a fall in pulse rate-was the same in all experiments. Some results are shown in detail in the Figures.

Noradrenaline (Fig. 1).-There was no potentiation in one experiment. A markedly lower control value of blood pressure after eight days on phenelzine, and probably due to it, complicated the interpretation. Ephedrine was strongly potentiated whether given intravenously (Fig. 2), one experiment, or orally (Fig. 3), four experiments. Phenylephrine was enormously

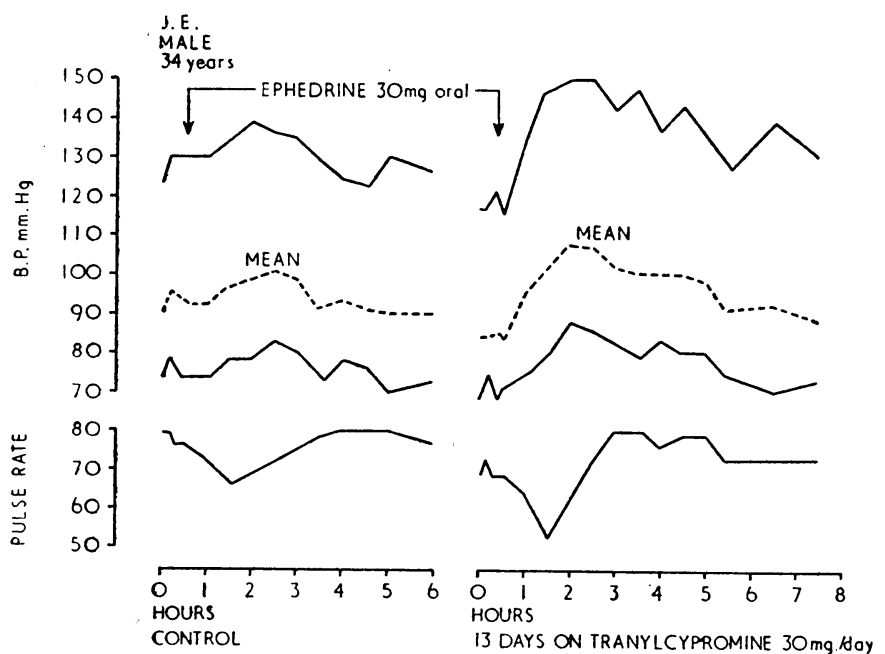

Fig. 3.-Effect of ephedrine orally on the blood pressure and heart rate before and during tranylcypromine administration. The rise in blood pressure is both increased and prolonged.
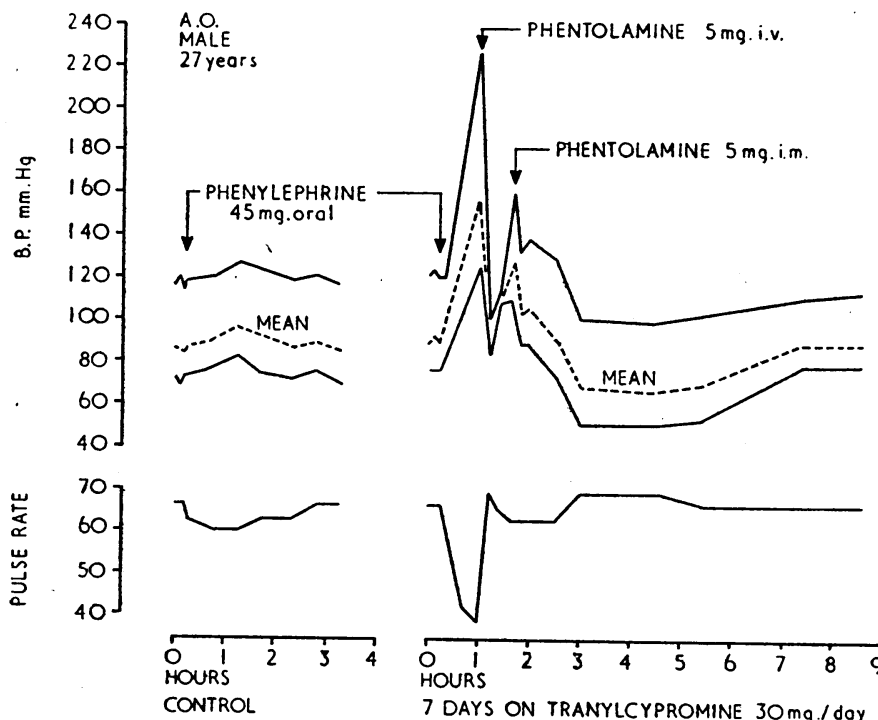

7 DAYS ON TRANYLCYPROMINE $30 \mathrm{mg} / /$ doY FIG. 4.- Effect of phenylephrine orally on the blood pressure and heart rate during tranylcypromine administration and 21 days afterwards (control). The rise in blood pressure is greatly increased and, reaching dangerous level, it was terminated by phentolamine. potentiated after oral administration (Fig. 4). The full extent is not shown in two of the three experiments, as they had to be terminated with phentolamine for reasons of safety.

After intravenous administration of $3 \mathrm{mg}$. of phenylephrine (Fig. 5), one experiment, the potentiation was marked but less dramatic than after oral administration.

A trivial symptomatic oral remedy for the common cold containing phenylephrine, paracetamol, ascorbic acid, caffeine, and $c$. quinine (Febs) was tested. The maximum 24-hour dose recom- $\overrightarrow{\vec{\prime}}$ mended by the manufacturer, containing $10 \mathrm{mg}$. of phenyl- 0 ephrine, was given as a single dose (Fig. 6), one experiment. There was marked potentiation.

Beer.-In a single experiment the blood pressure did not change after 1 pint $(570 \mathrm{ml}$.) of Guinness beer was drunk by a $\triangle$ subject taking phenelzine.

\section{Choice of Drugs}

Monoamine Oxidase Inhibitors.-Two monoamine oxidase inhibitors, representing each of the two main chemical groups, hydrazine (phenelzine) and non-hydrazine (tranylcypromine), were used.

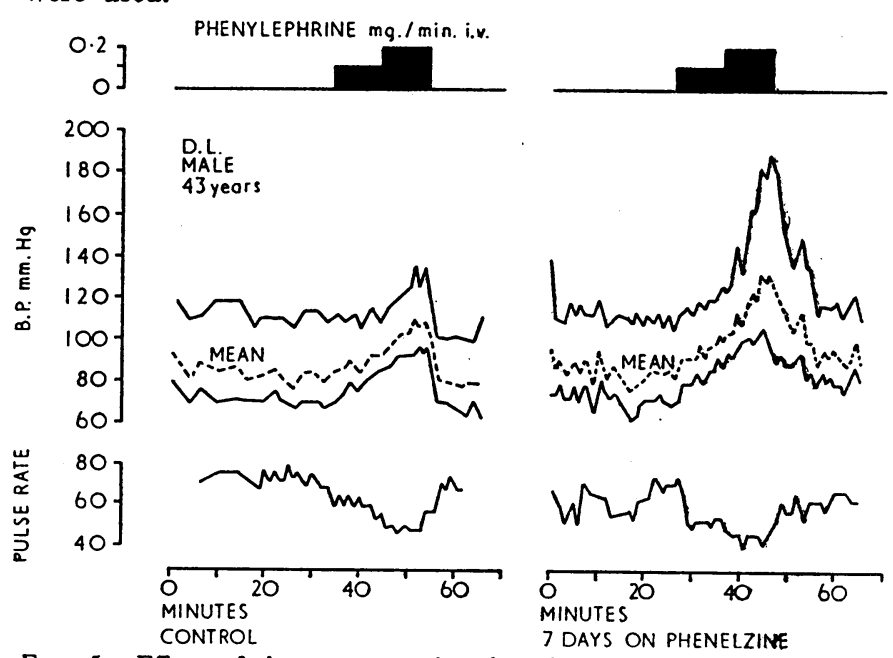

Fig. 5.-Effect of intravenous phenylephrine on the blood pressure and pulse rate before and during tranylcypromine administration. The rise in blood pressure is moderately increased.

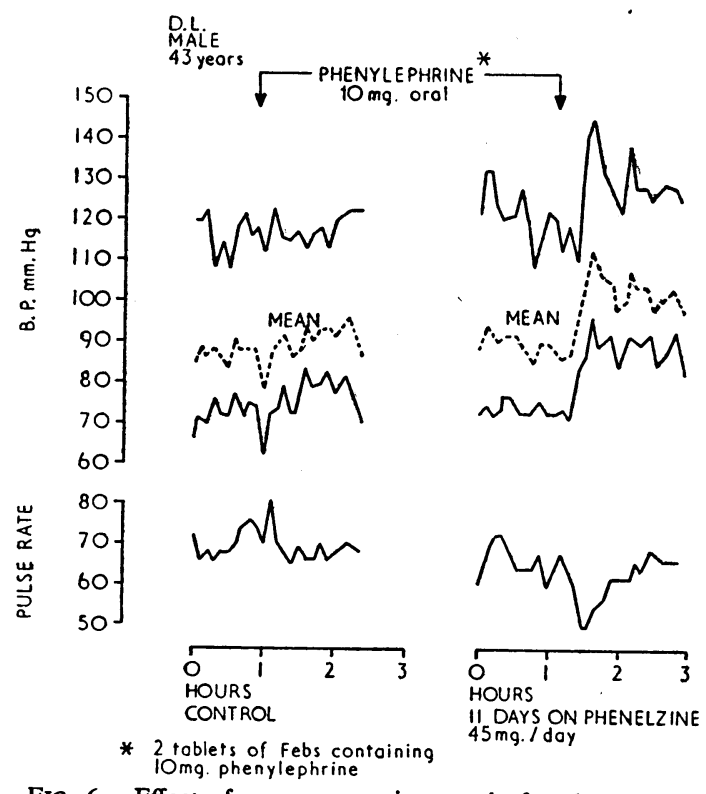

FIG. 6.-Effect of a symptomatic remedy for the common cold (containing phenylephrine) before and during phenelzine administration. The total dose advised by the There was no effect on blood pressure in the control experiment, but after the phenelzine a moderate rise with bradycardia occurred. 
Sympathomimetics.-Three kinds were chosen: (1) noradrenaline, the principal catecholamine adrenergic neurotransmitter and a substrate for monoamine oxidase ; (2) ephedrine, a synthetic and natural drug acting chiefly indirectly by discharging noradrenaline from its stores at nerve endings; it is unaffected by monoamine oxidase, and absorption from the intestine and passage through the liver (both of which contain much monoamine oxidase) should not be modified by monoamine oxidase inhibition; and (3) phenylephrine, a synthetic drug thought to act largely directly on adrenergic receptors, with little indirect-that is, noradrenaline-releasing-effect ; it is a substrate for monoamine oxidase, and for this reason the oral dose generally suggested is about 50 times that given intramuscularly. Absorption from the intestine should be enhanced by monoamine oxidase inhibition, and inactivation during passage through the liver should be reduced.

\section{Discussion}

The results of the experiments can be considered in the light of current views of the physiology of peripheral adrenergic nerve endings.

The chief function of monoamine oxidase, which is in the mitochondria at adrenergic nerve endings, may be to metabolize the noradrenaline that leaks from the storage granules into the neurone cytoplasm and escapes re-uptake into granules. When a nerve impulse causes discharge of noradrenaline from the ending this acts on the cell membrane of the effector organ, and the duration of its action is limited primarily by uptake into nerve cytoplasm and storage granules and to a lesser extent by diffusion away from the ending where metabolism occurs due to the enzyme catechol-O-methyltransferase.

The notion that the duration of the action of noradrenaline is determined by enzymic destruction at the ending, as is the case with acetylcholine, is now known to be untrue.

Thus when monoamine oxidase is inhibited the tissue stores of noradrenaline are increased, but the mechanisms for disposing of noradrenaline released as neurotransmitter or injected into the circulation are not disturbed other than by the limitation on tissue uptake imposed by the greater tissue stores.

\section{Noradrenaline}

From the above it is not to be expected that administered noradrenaline should be importantly potentiated by monoamine oxidase inhibition, and this has been shown in man by Horwitz et al. (1960), though they also found that if the arterial pressure was lowered by the monoamine oxidase inhibitor (some have adrenergic neurone-blocking activity too), then some potentiation did occur. The mechanism of this is not clear, but comparison of rises of blood pressure from different baselines is fraught with possibilities of error. Because of the observations of Horwitz et al. (1960) we did not proceed further when our single experiment with noradrenaline was seen to agree with their results. There is no reason to expect that adrenaline or noradrenaline included in local anaesthetics will be specially harmful in patients taking monoamine oxidase inhibitors.

\section{Ephedrine}

Because ephedrine acts chiefly by releasing noradrenaline from stores at nerve endings and monoamine oxidase inhibition increases these stores, it can be expected that a greater release might occur, with an effect that is both greater and more prolonged. Because ephedrine is not a substrate for monoamine oxidase, potentiation of oral and intravenous administration should be of about the same order, allowing for the different routes of administration. Figs. 2 and 3 and the Table show that these expectations are fulfilled; potentiation, measured by the percentage rise in mean arterial pressure, is about three to four times, but this figure and that given below cannot be taken as definitive owing to the few experiments.

\section{Phenylephrine}

Because phenylephrine is thought to act chiefly directly on receptors, and only to a small extent by releasing stored noradrenaline from nerve endings, little potentiation of the drug given intravenously would be expected after monoamine oxidase inhibition, and only a moderate amount occurred (Fig. 5) (the percentage rise of the mean arterial pressure was about twice the control). Because phenylephrine is a substrate for monoamine oxidase, and so is altered in the intestinal wall and in the liver, it might be expected that an oral dose that only just raises the blood pressure in a control might be greatly potentiated by monoamine oxidase inhibition. This proved to be the case (Fig. 4) to such an extent that in three experiments in which $45 \mathrm{mg}$. was used the rise of blood pressure, which was trivial in the control, became potentially disastrous and had to be arrested by an $\alpha$-adrenergic receptor blocking drug (phentolamine), so that the maximum rise that might have occurred remains unknown. Potentiation was about 13 times in the only experiment that did not have to be thus stopped. It was six and 35 times in the two that had to be stopped with phentolamine.

Results of experiments after oral administration are likely to be extremely variable owing to widely differing rates of absorption added to variable degrees of monoamine oxidase inhibition.

In the experiment shown in Fig. 4 the blood pressure rose with great speed, and the rise was arrested (when the diastolic pressure had reached $120 \mathrm{~mm}$. $\mathrm{Hg}$ ) by intravenous phentolamine. A second dose was given intramuscularly as a precaution when the blood pressure began to rise again. The rise of blood pressure was accompanied by severe headache.

We think that when a hypertensive attack occurs in any patient taking a monoamine oxidase inhibitor it is a matter of urgency to administer an $\alpha$-adrenergic blocking drug, because the blood pressure can rise to dangerous heights extremely fast. Phentolamine is the obvious choice, as it is well tried, safe, and easily handled. Chlorpromazine (a phenothiazine tranquillizer with $\alpha$-adrenergic blocking effect) or an allied drug has been used, and may well be adequate. They should be injected.

The well-known dangerous pressor effect of certain foods which contain tyramine and other sympathomimetic substrates for monoamine oxidase results from the same mechanism as with phenylephrine.

\section{Summary}

A series of experiments were carried out in normal volunteers in an attempt to get some measure of the size of the risk of serious rise in blood pressure when commonly used sympathomimetics are given after monoamine oxidase inhibitors.

Injected noradrenaline is not importantly inactivated by monoamine oxidase, and is not potentiated.

Ephedrine acts by releasing stored noradrenaline from nerve endings. These rtores are increased by inhibition of monoamine oxidase, and ephedrine is substantially potentiated. Potentiation is about equal whether the drug is given orally or intravenously.

Phenylephrine acts only partially by releasing stored noradrenaline, and so is moderately potentiated by monoamine oxidase inhibition when given intravenously. But phenylephrine is a substrate for monoamine oxidase, and so, when given orally, is normally largely destroyed in the gut wall and liver. Thus after monoamine oxidase inhibition absorption is greater and a dangerous potentiation occurs. This can be immediately relieved by an $\alpha$-adrenergic blocking drug such as phentolamine.

We are grateful to Dr. B. Blackwell for advice on the choice of monoamine oxidase inhibitors.

REFERENCE

Horwitz, D., Goldberg, L. I., and Sjoerdsma, A. (1960). F. Lab. clin Med., 56, 747. 